\title{
Chemical composition of organs of children who died from malnutrition
}

\author{
By G. A. O. ALLEYNE, D. HALLIDAY AND J. C. WATERLOW \\ Medical Research Council, Tropical Metabolism Research Unit, \\ University of the West Indies, Kingston, Famaica
}

AND B. L. NICHOLS

Baylor College of Medicine, and Texas Children's Hospital, Houston, Texas

(Received 31 December 1968-Accepted 21 April 1969)

\begin{abstract}
1. Chemical analysis was carried out on samples of brain, liver, skeletal muscle, heart and kidney obtained from children who died of malnutrition. Total body potassium was measured before autopsy by the 'whole body counting' technique.

2. There was a marked increase in liver fat, and the brain contributed a higher percentage of the body-weight in the more severely malnourished children.

3. All the organs had approximately the same concentrations of non-collagen nitrogen. The proportion of collagen was highest in muscle.

4. All organs were depleted of potassium, but the muscle was most severely affected. Brain potassium as a percentage of total body potassium was higher than normal in the most severely potassium depleted children.

5. Measurements of tissue magnesium showed that there was no difference in magnesium content of tissues when expressed in terms of non-collagen nitrogen. When compared with normal values, muscle was magnesium depleted. The potassium to magnesium ratio was lowest in muscle.
\end{abstract}

It is accepted that, with dietary deprivation, changes in total body or specific organ metabolism may take place. It is also true that changes in organ composition may precede or follow these changes in function. In an attempt to investigate the structural changes associated with death from protein-calorie malnutrition, several whole body cadaver analyses have been undertaken in this Unit (Garrow, Fletcher \& Halliday, 1965; Halliday, 1968). In the study reported here we have attempted to focus on the composition of some of the vital organs from children dying with protein-calorie malnutrition. Also by measuring total body potassium (TBK) before autopsy, it has been possible to relate some of the electrolyte measurements to TBK in a manner that was not previously possible.

\section{MATERIAL AND METHODS}

We studied eleven children who died from severe protein-calorie malnutrition shortly after admission to hospital. TBK was measured before autopsy in a Packard 4 pi whole body counter. The method of counting has already been described (Garrow, I965a). At autopsy, samples of brain, liver, muscle, heart and kidney were obtained after the organ weights had been recorded. In every instance the sample was taken from the following sites: brain was taken from the frontal pole, including approximately equal quantities of grey and white matter; liver was taken from the anterior 
portion of the left lobe; the muscle sample was a cross-section of one gastrocnemius; heart was a segment of the left ventricular wall to include the apex; kidney, after longitudinal section, was from half of the lower pole to include both cortex and medulla.

The samples were collected into tared bottles, and dried to constant weight in an oven at approximately $95^{\circ}$. Fat was extracted by repeated washings with petroleum ether, and fat content calculated by differences in weight. The dried fat-extracted material was finely ground in a mortar, and the resulting powder used for analysis. Total nitrogen was measured by Kjeldahl digestion of the fat-free powder. Collagen nitrogen was measured by estimating the tissue total hydroxyproline content and applying a conversion factor of 7.09 (Neuman $\&$ Logan, 1950). Tissue potassium was measured by external standard flame photometry after dissolving the tissue in 0.2 $\mathrm{N}$-lithium hydroxide. Magnesium was estimated by atomic absorption spectrophotometry after dry ashing the tissue at $45^{\circ}$ and dissolving the ash in $0 \cdot 1 \mathrm{~N}-\mathrm{HNO}_{3}$.

The children for whom the values for brain weight relative to body-weight deficit are presented represent the original eleven children, plus thirty-four unselected children in whom the diagnosis of malnutrition was made before death and whose bodies were autopsied in the Pathology Department of the University of the West Indies.

\section{Table r. Clinical details and total body potassium in the eleven malnourished children studied}

\begin{tabular}{|c|c|c|c|c|c|c|c|c|}
\hline Child & $\begin{array}{c}\text { Age } \\
\text { (months) }\end{array}$ & Sex & $\begin{array}{c}\text { Body-wt } \\
\text { (kg) }\end{array}$ & Oedema & $\begin{array}{c}\text { Height } \\
\text { (cm) }\end{array}$ & $\begin{array}{c}\mathrm{W}^{\top} \mathrm{t} \text { as } \\
\% \text { of } \\
\text { ideal } \mathrm{wt}^{*}\end{array}$ & $\begin{array}{c}\text { Haemo- } \\
\text { globin } \\
(\mathrm{g} / \mathrm{r} 00 \mathrm{ml})\end{array}$ & $\begin{array}{c}\text { Total body } \\
\text { potassium } \\
\text { (m-equiv./kg) }\end{array}$ \\
\hline G.F. & 7 & $0 *$ & 4.40 & 0 & 60.0 & $79 \cdot 3$ & 4.9 & $28 \cdot 7$ \\
\hline L.H. & 16 & $\hat{\jmath}$ & $5 \cdot 93$ & + & $67 \cdot 5$ & $74 \cdot 6$ & $6 \cdot 3$ & $33 \cdot 8$ \\
\hline R.R. & 8 & $\hat{0}$ & $4 \cdot 48$ & 0 & $61 \cdot 0$ & $76 \cdot 6$ & 8.0 & $29^{\circ} \mathrm{I}$ \\
\hline P.I. & 16 & $\hat{O}$ & $6 \cdot 36$ & 0 & $72 \cdot 0$ & 68.4 & $11 \cdot 1$ & $35 \cdot 3$ \\
\hline A.T. & I 5 & 0 & $5 \cdot 94$ & 0 & 69.5 & $69 \cdot 5$ & - & $38 \cdot 4 t$ \\
\hline A.M. & I 3 & 우 & 7.90 & + & $77^{\circ} 0$ & $75 \cdot 6$ & -- & $37 \cdot 7$ \\
\hline Pk.W. & 6 & $\delta$ & $5 \cdot 50$ & + & $63^{\circ} \circ$ & $84 \cdot 6$ & --- & $37 \cdot 7$ \\
\hline G.M. & $r_{3}$ & $a$ & $6 \cdot 92$ & + & $72 \cdot 3$ & 74.0 & 10.1 & 297 \\
\hline C.C. & 9 & 0 & 4.70 & 0 & 61.0 & $80 \cdot 3$ & - & $36 \cdot 4$ \\
\hline R.N. & 8 & 우 & 5.70 & 0 & $63^{\circ} 0$ & 87.7 & 7.2 & $37 * 5$ \\
\hline P.W. & 7 & 우 & 5.27 & + & $63 \cdot 3$ & 80.5 & $8 \cdot 8$ & $28 \cdot 8$ \\
\hline
\end{tabular}

\section{RESULTS}

Table I gives some clinical information about the children on admission to hospital. With the exception of R.N., they all had a previous history of diarrhoea. Total body potassium was measured on admission in L.G. and after he died 4 days later. A total of $40 \mathrm{~m}$-equiv. of supplementary potassium was given orally and his body potassium rose from $155 \mathrm{~m}$-equiv. to $200 \mathrm{~m}$-equiv. in that time, indicating total retention of the potassium given.

In Table 2 the water and fat content of the organs are shown. 'The percentage of 
water in the brain was significantly higher than that in muscle $(P<0.001)$, heart $(P<0.05)$ and kidney $(P<0.05)$. There was no significant difference in water content between muscle, heart or kidney. The most striking feature, however, is the high fat and low water content of the liver.

\section{Table 2. Water and fat content as percentages of the wet weights of the tissues of the eleven malnourished children}

(Mean values and standard deviations)

$\begin{array}{lcc}\text { Tissue } & \text { Water } & \text { Fat } \\ \text { Brain (II) } & 84 \cdot 0 \pm 2 \cdot 8 & \mathbf{5} \cdot 7 \pm \mathrm{I} \cdot 9 \\ \text { Liver (II) } & 64 \cdot 0 \pm 8 \cdot 6 & \mathrm{I} 8 \cdot 6 \pm \mathrm{I2} \cdot \mathbf{2} \\ \text { Muscle (II) } & 76 \cdot 9 \pm 5 \cdot \mathrm{I} & 4 \cdot 7 \pm 2 \cdot 7 \\ \text { Heart (9) } & 80 \cdot 4 \pm 2 \cdot 7 & \mathrm{I} \cdot 9 \pm \mathrm{I} \cdot 6 \\ \text { Kidney (IO) } & 80 \cdot 5 \pm 3 \cdot 9 & 2 \cdot 1 \pm 2 \cdot 7\end{array}$

The number of samples is given in parentheses.

Table 3. Nitrogen content of the tissues analysed from the eleven malnourished children (for derivation of the total body $N$ see below)

\begin{tabular}{|c|c|c|c|c|}
\hline \multicolumn{5}{|c|}{ (Mean values and standard deviations) } \\
\hline Tissue & $\begin{array}{c}\text { Total N } \\
(\mathrm{mg} / \mathrm{g} \text { FFDT })\end{array}$ & $\begin{array}{r}\text { Collagen N } \\
(\mathrm{mg} \text { DFFT) }\end{array}$ & Total N (g) & $\begin{array}{c}\text { Total body } N \\
(\%)\end{array}$ \\
\hline Brain & $117 \cdot 2 \pm 8 \cdot 1(11)$ & None & $9 \cdot 4 I \pm I \cdot 6(\mathrm{II})$ & $8 \cdot I \pm I \cdot I$ \\
\hline Liver & $127.7 \pm 10.1$ (II) & $8 \cdot 1+4 \cdot 6(9)$ & $5.74 \pm 2.5(11)$ & $4.7 \pm 1 \cdot 7$ \\
\hline Muscle & $147 \cdot 9 \pm$ II.O(II) & $26 \cdot 2 \pm 17 \cdot 5(8)$ & - & $=$ \\
\hline Heart & $133.4 \pm 4.5(9)$ & $11 \cdot 5 \pm 2 \cdot 6(7)$ & $0.83 \pm 0.24(9)$ & $0.67 \pm 0.36$ \\
\hline Kidney & $129 \cdot 7 \pm 5.1$ (II) & $12 \cdot 1 \pm 3.6$ (IO) & $I \cdot 04 \pm 0.36(10)$ & $0.83 \pm 0.21$ \\
\hline
\end{tabular}

The numbers in parentheses are the numbers of samples analysed. DFFT, dry fat-free tissue.

The nitrogen content of the organs is shown in Table 3 . Muscle contained the highest concentration of total nitrogen, but this is probably related to the amount of collagen nitrogen present. In terms of non-collagen nitrogen per $g$ of fat-free dry tissue, there were no differences between the values for the five tissues; approximately $120 \mathrm{mg}$ of noncollagen nitrogen per $g$ fat-free solids. There was no measurable collagen in brain. The total organ nitrogen was calculated from the total organ weight, and the total body nitrogen derived by use of a figure of 1.67 for the whole body potassium to nitrogen ratio. This value was obtained from whole body analyses of similar malnourished children (Halliday, I968). Thus, since the total body potassium was known, an approximate value for total body nitrogen could be obtained. Brain contributed more to the total body nitrogen than any of the other three visceral organs.

The results of the potassium estimations are given in Table 4 . Tissue potassium is expressed in several ways but total organ potassium is easily calculated from the known organ weights and appropriate tissue concentration, always with the assumption that a sample is representative of the whole organ. There was little inter-organ variation in potassium content per $\mathrm{kg}$ wet tissue, but in terms of fat-free dry weight and nitrogen there were marked differences. Brain consistently had the highest and muscle the 
lowest potassium content per $\mathrm{kg}$ fat-free dry tissue and per $\mathrm{g}$ total nitrogen. Without a figure for total muscle mass it is impossible to calculate the contribution of muscle potassium to total body potassium, but of the other tissues brain contributes by far the greatest fraction of the body potassium.

Table 4. Potassium content of tissues of the eleven malnourished children

(Mean values and standard deviations)

\begin{tabular}{|c|c|c|c|c|c|c|}
\hline \multirow[b]{2}{*}{ Tissue } & \multirow[b]{2}{*}{$\begin{array}{l}\text { m-equiv. } / \mathrm{kg} \\
\text { wet wt }\end{array}$} & \multicolumn{3}{|c|}{ (Mean values and standard deviations) } & \multicolumn{2}{|c|}{ Total organ $\mathrm{K}$} \\
\hline & & $\begin{array}{l}\text { m-equiv. } / \mathrm{kg} \\
\text { DFFT }\end{array}$ & $\begin{array}{l}\text { m-equiv./g } \\
\text { total } \mathrm{N}\end{array}$ & $\begin{array}{l}\text { m-equiv./g } \\
\text { NCN }\end{array}$ & m-equiv. & $\begin{array}{l}\text { As \% of } \\
\text { TBK }\end{array}$ \\
\hline Brain & $\begin{array}{l}51 \cdot 4 \pm 5 \cdot 7 \text { (II) } \\
46 \cdot 5 \pm 14.1 \text { (II) }\end{array}$ & $\begin{array}{l}492 \pm 55 \\
265 \pm 30\end{array}$ & $\begin{array}{l}4.00 \pm 0.81 \\
2.02 \pm 0.27\end{array}$ & $2.22 \pm 0.25$ & $\begin{array}{l}39 \cdot 6 \pm 5 \cdot 7 \\
12 \cdot 0 \pm 5.6\end{array}$ & $\begin{array}{r}20 \cdot 5 \pm 3 \cdot 9 \\
6 \cdot 0 \pm 2 \cdot 3\end{array}$ \\
\hline Muscle & $46 \cdot 6 \pm 14.6$ (II) & $252 \pm 15$ & $I \cdot 66 \pm 0.40$ & $2.15 \pm 0.40$ & - & - \\
\hline $\begin{array}{l}\text { Heart } \\
\text { Kidney }\end{array}$ & $\begin{array}{l}51 \cdot 3 \pm 11 \cdot 3(9) \\
44 \cdot 9 \pm 9 \cdot 4(10)\end{array}$ & $\begin{array}{l}285 \pm 47 \\
261 \pm 38\end{array}$ & $\begin{array}{l}2.14 \pm 0.43 \\
2.02 \pm 0.40\end{array}$ & $\begin{array}{l}2 \cdot 50 \pm 0.37 \\
2 \cdot 39 \pm 0.18\end{array}$ & $\begin{array}{l}2.0 \pm 0.4 \\
2 \cdot 1 \pm 0.9\end{array}$ & $\begin{array}{l}0.9 \pm 0.4 \\
1.0 \pm 0.3\end{array}$ \\
\hline
\end{tabular}

The number of samples analysed is given in parentheses. DFFT, dry fat-free tissue; NCN, noncollagen nitrogen; TBK, total body potassium.

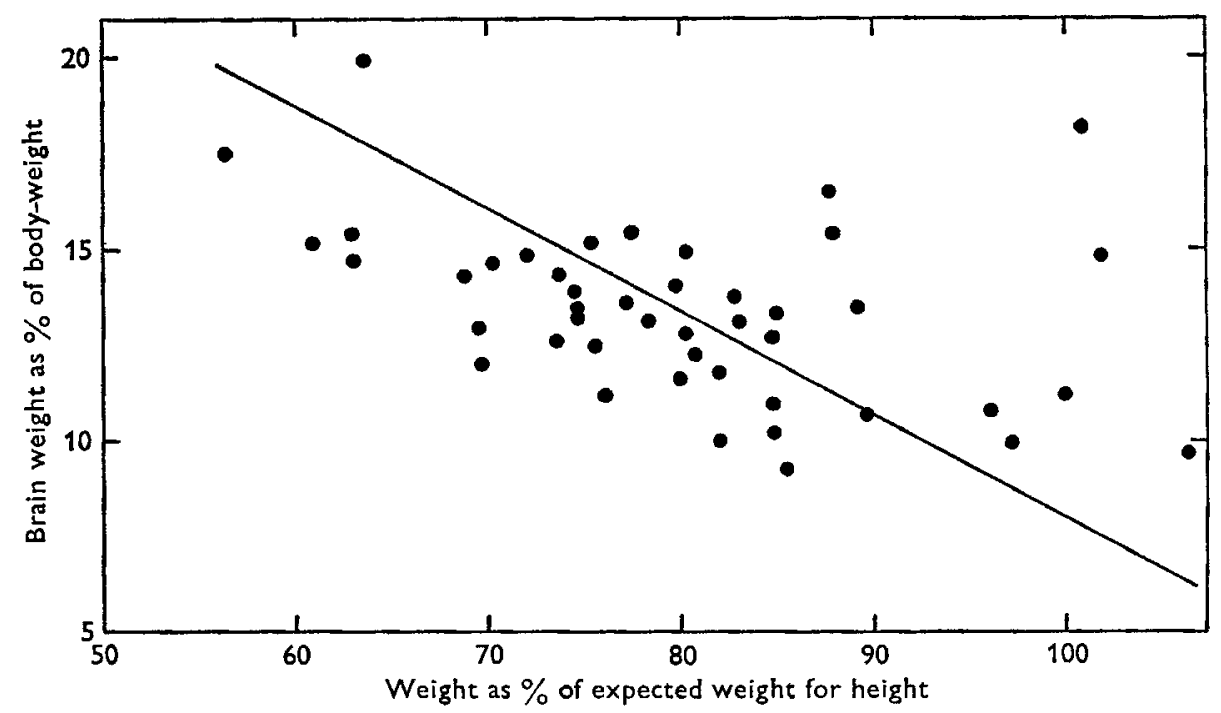

Fig. 1. Relationship between weight deficit and the brain weight as a percentage of bodyweight in forty-five children diagnosed as being malnourished. $r=-0.42 ; P<0.005 ; y=$ $-0 \cdot 27 x+35$.

The brain potassium and the relative contributions of brain to body composition have been examined more closely. In Fig. $\mathrm{I}$ is shown the relationship between brain weight as percentage of body-weight and the weight deficits in forty-five children. In more severely malnourished children the brain contributed a greater share to the body-weight, or perhaps brain is relatively well preserved in malnutrition. In Fig. 2 brain potassium as a percentage of total body potassium is related to total body potassium. As the total body potassium fell below $30 \mathrm{~m}$-equiv. $/ \mathrm{kg}$, the percentage contributed by the brain rose significantly. 
The values for tissue magnesium are shown in Table 5. The brain had the highest and muscle the lowest magnesium concentration. When the potassium to magnesium ratio was calculated, it was the same for liver, heart and kidney, high in brain and low in muscle.

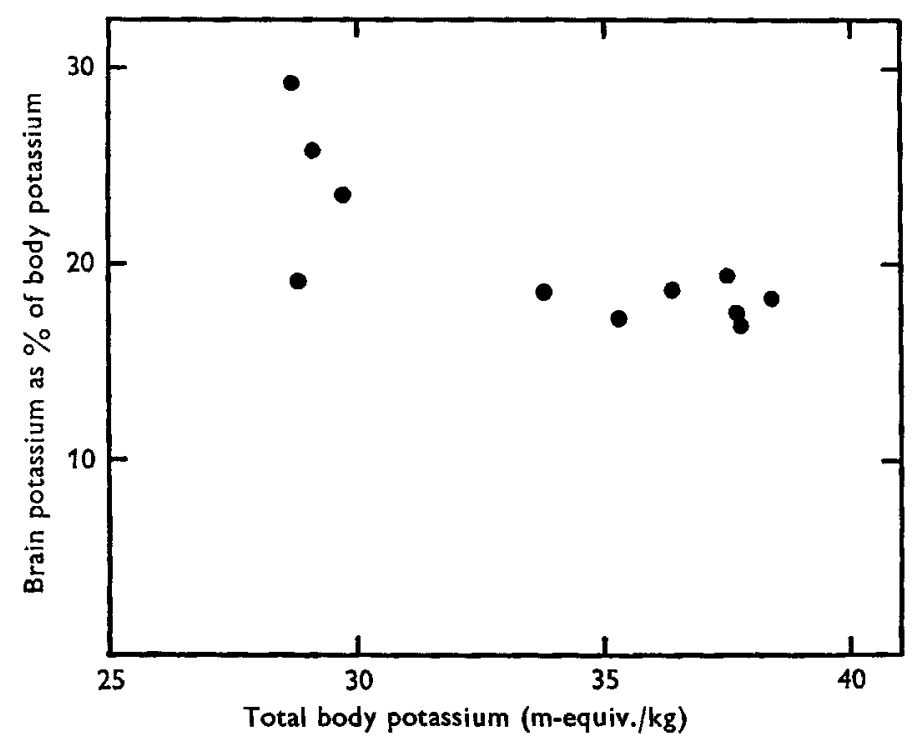

Fig. 2. Relationship between total body potassium and the percentage of the total body potassium contributed by the brain in the eleven malnourished children.

Table 5. Magnesium content of tissues of the eleven malnourished children

(Mean values and standard deviations)

\begin{tabular}{|c|c|c|c|c|}
\hline \multirow[b]{2}{*}{ Tissue } & \multicolumn{3}{|c|}{ 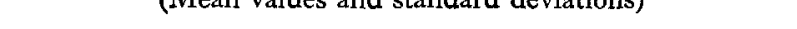 } & \multirow{2}{*}{$\begin{array}{l}\text { Ratio, potassium } \\
\text { magnesium }\end{array}$} \\
\hline & m-equiv./kg DFFT & m-equiv./g N & m-equiv./g NCN & \\
\hline Brain & $72-6 \pm 14 \cdot 5(8)$ & $0.63 \pm 0.14$ & 一 & $7 \cdot 2 \pm 3 \cdot 1$ \\
\hline Liver & $60.3 \pm 19.5$ (10) & $0.48 \pm 0.14$ & $0.50 \pm 0.15$ & $4 \cdot 7 \pm x \cdot 1$ \\
\hline Muscle & $49 \cdot 0 \pm 3 \cdot 3$ & $0.33 \pm 0.01$ & $0.43 \pm 0.08$ & $3 \cdot 7 \pm 1 \cdot 0$ \\
\hline Heart & $61 \cdot 7 \pm 13.8(7)$ & $0.46 \pm 0.10$ & $0.53 \pm 0.09$ & $4.8 \pm 0.9$ \\
\hline Kidney & $54 \cdot 8 \pm 5 \cdot 0(8)$ & $0.42 \pm 0.07$ & $0.47 \pm 0.06$ & $4.7 \pm 0.9$ \\
\hline
\end{tabular}

The number of samples analysed is given in parentheses. DFFT, dry fat-free tissue; NCN, non-collagen nitrogen.

\section{DISCUSSION}

In the absence of any similar study on autopsy samples in adequately nourished Jamaican children of this age group, it is impossible to draw firm conclusions from some of the results presented. More emphasis therefore will be placed on a comparison of the values for the different tissues, in an attempt to determine if and how their compositions are changed differentially by malnutrition. A basic assumption inherent in calculating the results is that the samples taken are representative of the whole organ.

The fat content of the liver was high, as has been shown on several previous occasions (Waterlow, 1948; Waterlow \& Weisz, 1956; Garrow et al. 1965). Waterlow \& Weisz (1956) showed that in children recovered from malnutrition fat was $3.1 \%$ of liver 
wet weight. There was no significant difference in water content between the samples of heart or kidney, but the water content of brain was higher than in any of the other tissues (Table I). This is to be expected from the data of Widdowson \& Dickerson (1964). The demonstration that the brain contributed a larger percentage to total body-weight in the more severely malnourished children may be a reflection of overhydration in that organ, but a far more likely explanation is that there is greater wasting of the rest of the body. Widdowson \& Dickerson (1964) have reported that the newborn baby's brain is $13.4 \%$ of body-weight, and this figure falls to $2.3 \%$ for the adult. From Fig. I it is clear that in several of the more severely malnourished children the brain weight as a percentage of body-weight was much higher than 13.4 . It is surprising that in these eleven children there was no significant increase in water content of muscle. The value of $76 \cdot 9 \%$ is close to that of $78 \cdot 5 \%$ given by Widdowson \& Dickerson (1964) for 4-7 months old children. It has previously been demonstrated that in malnutrition there is an increase in body water and extracellular fluid (Smith, 1960; Alleyne, I968).

In all tissues except brain, there was a significant collagen nitrogen fraction-in muscle reaching $15 \%$ of the total nitrogen. There was a wide variation in muscle collagen, and in one child who actually had the lowest total body potassium the muscle collagen nitrogen was $45 \%$ of the total nitrogen. The high collagen content of the body as a whole and of muscle in particular has been demonstrated before in such infants (Picou, Halliday \& Garrow, I966; Halliday, 1966). The four organs measured here only contributed $10 \%$ of the total nitrogen. It has been shown in malnutrition that a considerable fraction of the total body nitrogen may reside in skin and bones (Halliday, 1966).

The severe deficit of potassium has been demonstrated by several workers (Hansen, 1956; Waterlow \& Mendes, 1957; Garrow, 1965 $b$; Alleyne, 1968). The distribution of the potassium loss is not quite clear. The muscle has been accepted as being the major reservoir of body potassium (Forbes \& Lewis, 1956) and there is a relationship between muscle potassium and total body potassium in potassium-depleted malnourished infants (Nichols, Alleyne, Hazlewood, Barnes \& Waterlow, I967). Garrow (1967) suggested that the brain may also be severely potassium-depleted in such children. The results presented here show that there is a deficit of potassium in all organs. Even in the newborn (Widdowson \& Dickerson, 1964) almost all tissues have potassium contents of over 55 m-equiv./ $\mathrm{kg}$ wet weight, rising to higher levels with maturation. If we take the figures of these authors for brain, the potassium is $5^{8 \cdot 2}$ m-equiv. $/ \mathrm{kg}$ in the newborn and $84.6 \mathrm{~m}$-equiv. $/ \mathrm{kg}$ in the adult, while the nitrogen content is $9.3 \mathrm{~g} / \mathrm{kg}$ in the newborn and $17.1 \mathrm{~g} / \mathrm{kg}$ in the adult. Thus potassium to nitrogen $(\mathrm{K} / \mathrm{N})$ ratios would be $6 \cdot 26$ and $4 \cdot 95$ in the two stages. Most of the fall in water content of the brain takes place between 8 and 2i months (MacArthur \& Doisy, r9I9); thus it would be a reasonable assumption that the brain $\mathrm{K} / \mathrm{N}$ in a I-year-old child is of the order of $5^{\circ} 3$. A similar figure for muscle is approximately $3^{\circ} \mathrm{o}$, for liver 2.3 , kidney 2.5 and heart 2.3 . The brain potassium in the newborn is approximately $15 \%$ of the total body potassium, falling as maturation progresses.

With these approximations the following tentative conclusions may be drawn from 
values for potassium presented here. The brain and visceral organs appear to be less depleted of potassium than muscle, since their $\mathrm{K} / \mathrm{N}$ ratios were nearer the normal value than that for muscle. Fig. 2 shows that with decreasing total body potassium brain potassium as a percentage of total body potassium rose. However, when brain $\mathrm{K} / \mathrm{N}$ is related to total body potassium, there was no change in $\mathrm{K} / \mathrm{N}$ over the range of total body potassium seen in these children. Thus it would appear that in malnutrition muscle bears the brunt of the potassium depletion, and loss from brain and other vital organs is modest. With increasing body depletion, brain, moderately depleted as it is, contributes more than normal to the total body potassium.

Magnesium is quantitatively the next most important intracellular cation; hence its distribution is also of interest. As with potassium, reasonable interpolations for a I-year-old infant may be made from the data of Widdowson \& Dickerson (I964). The brain magnesium to nitrogen ratio falls from a value of 0.85 at birth to 0.67 in the adult. For babies 4-7 months old, the figure for liver is 0.48 , for muscle 0.69 , heart 0.52 , while for kidney the value is 0.45 for newborns and 0.35 for adults. It is apparent that muscle was again most depleted, and the other tissues had fairly normal concentrations of magnesium relative to nitrogen. In biopsy samples from similar children, Montgomery (1960) has demonstrated a reduction in muscle magnesium. The potassium to magnesium ratio when calculated again from the Widdowson \& Dickerson data shows normal values of 7.4 for brain, $5^{.6}$ for liver, $5^{\circ} \circ$ for muscle, 4.5 for heart and 6.5 for kidney. Comparison of these figures with those in our small series would indicate that in muscle, more potassium was lost than magnesium. In contrast with potassium, bone rather than muscle is the major store for magnesium; hence in the most severely malnourished and electrolyte-depleted children, the magnesium levels in the soft tissues might be kept up at the expense of bone, and thus potassium to magnesium ratios would tend to fall. It is very relevant to note that in electrolytedepleted rats Whang \& Welt ( 1963$)$ found that, with severe potassium and magnesium depletion, muscle was always more depleted of potassium than magnesium and the potassium to magnesium ratio fell.

The authors are grateful to the Department of Pathology, UWI, for access to their autopsy material. The skilled technical assistance of Miss Stephanie Campbell and Mrs C. Ragbeer is acknowledged.

\section{REFERENCES}

Alleyne, G. A. O. (1 968). Clin. Sci. 34, 199.

Forbes, G. B. \& Lewis, A. M. (1956). F. clin. Invest. 35, 596.

Garrow, J. S. (1965a). W. Indian med. F. 14, 73.

Garrow, J. S. (1965b). Lancet ii, 455.

Garrow, J. S. (1967). Lancet ii, 643 .

Garrow, J. S., Fletcher, K. \& Halliday, D. (1965). J. clin. Invest. 44, 4 I7.

Halliday, D. (I966). Body composition in severe infantile protein malnutrition. $\mathrm{PhD}$ Thesis, University of London.

Halliday, D. ( 968 ). Clin. Sci. 33, 365 .

Hansen, J. D. L. (1956). S. Afr. F. Lab. clin. Med. 2, 206.

MacArthur, C. G. \& Doisy, E. A. (1919). F. comp. Neurol. 3o, 445.

Montgomery, R. D. (I960), Lancet ii, 74. 
Nelson, W. E. (1957). Textbook of Pediatrics, 7 th ed. Philadelphia: Saunders.

Neuman, R. E. \& Logan, M. A. (1950). F. biol. Chem. 184, 299.

Nichols, B. L., Alleyne, G. A. O., Hazlewood, C., Barnes, D. J. \& Waterlow, J. C. (1967). Fedn Proc. Fedn Am. Socs exp. Biol. 26, 304.

Picou, D., Halliday, D. \& Garrow, J. S. (1966). Clin. Sci. 3o, 345.

Smith, R. (1960). Clin. Sci. 19, 275.

Waterlow, J. C. (1948). Spec. Rep. Ser. med. Res. Coun. no. 263.

Waterlow, J. C. \& Mendes, C. B. (1957). Nature, Lond. 180, 136r.

Waterlow, J. C. \& Weisz, T. (1956). F. clin. Invest. 35, 346.

Whang, R. \& Welt, L. G. (1963). F. clin. Invest. 42, 305.

Widdowson, E. M. \& Dickerson, J. W. T. (1964). In Mineral Metabolism. Vol. 2, Part A, p. I. [C. L. Comar and F. Bronner, editors.] New York and London: Academic Press Inc. 